\title{
Evaluation of the functional properties of bael powder using different drying methods
}

\author{
Vipul Chaudhary, Vivak Kumar, B.R. Singh, Jaivir Singh, Neelash Chauhan and Pushpendra Kumar
}

The study were carried out to evaluate the effect of different varieties of bael (Pant Aparna, Pant Shivani and Pant Urvashi) dried by different method such as open sun drying, tray drying $\left(60^{\circ} \mathrm{C}\right.$ and $\left.70^{\circ} \mathrm{C}\right)$ and hot air oven drying $\left(60^{\circ} \mathrm{C}\right.$ and $70^{\circ} \mathrm{C}$ ) on functional properties of bael powder. The functional properties such as swelling capacity, water absorption capacity, oil absorption capacity, foam capacity, solubility and bulk density were decreased with increase in drying temperature. The result showed that the Variety Pant Aparna at $60^{\circ} \mathrm{C}$ cabinet tray drying and Variety Pant Aparna by open sun drying bael powder had highest functional properties compared to others treated bael powder. Bael powder has good functional properties which enhance the nutritional quality of the value added products.

Key Words : Swelling capacity, Foam capacity, Bulk density, Solubility index, Water absorption capacity, Oil absorption capacity

How to cite this article : Chaudhary, Vipul, Kumar, Vivak, Singh, B.R., Singh, Jaivir, Chauhan, Neelash and Kumar, Pushpendra (2020). Evaluation of the functional properties of bael powder using different drying methods. Food Sci. Res. J., 11(2): 47-55, DOI :

10.15740/HAS/FSRJ/11.2/47-55.Copyright@2020: Hind Agri-Horticultural Society. 